\title{
Effect of Calcium Application on Fruit Quality of Apples Produced in Warm Regions
}

\author{
Satoru Kondo and Sutthiwal SETHA \\ Graduate School of Applied Biosciences, Hiroshima Prefectural University, \\ Shobara, Hiroshima 727-0023, Japan
}

(Received July 14, 2004)

\begin{abstract}
The effects of calcium (Ca) application on fruit firmness, ethylene concentration and Ca uptake of 'Jonagold' apple [Malus sylvestris (L.) Mill. var. domestica (Borkh.) Mansf.] were investigated. A $2.5 \mathrm{~g} \cdot \mathrm{L}^{-1} \mathrm{Ca}\left(1.425 \mathrm{~g} \cdot \mathrm{L}^{-1}\right.$ calcium sulphate dihydrate, $0.675 \mathrm{~g} \cdot \mathrm{L}^{-1}$ calcium chloride and $0.4 \mathrm{~g} \cdot \mathrm{L}^{\prime}$ others) solution was applied to whole tree at 4 days intervals from 20 to 60 days after full bloom (DAFB). Ca treatment decreased internal ethylene concentration compared to the untreated control. Bound Ca concentration in the cell wall of $\mathrm{Ca}$-treated fruit was higher than that of untreated control. Although the firmness of Ca-treated fruit showed higher value than that of the control before coloring, they had no significant difference after coloring. These results demonstrate that $\mathrm{Ca}$ treatment at 20-60 DAFB may prevent the increase of ethylene production, resulting in the delay of fruit senescence, prior to coloring, which is often observed in warm regions.
\end{abstract}

Keywords : cell wall calcium, fruit firmness, senescence, soluble calcium

\section{INTRODUCTION}

Post-harvest infiltration treatment of calcium increases fruit firmness and lengthens storage life (Siddiqui and Bangerth, 1993). Calcium is generally applied five or more times during fruit development to prevent physiological disorders such as bitter pit, but the effect on firmness is various (Bramlage et al., 1974; Cooper and Bangerth, 1976; Siddiqui and Bangerth, 1995). The difference in the results for each experiment may be due to different application times of calcium. Since cuticle cells in the peel form with fruit development, the infiltration into the fruit by the calcium application may be more effective for young fruit. However, the effect due to application time of calcium on fruit firmness is unclear.

In general, apple fruit produced in warm regions [beyond a warmth index of $90^{\circ} \mathrm{C}$ (the average monthly temperatures minus $5^{\circ} \mathrm{C}$ totaled ignoring months with negative values)] cannot maintain post-harvest firmness and often reach a state of senescence on the tree (Kikuchi, 1998). Therefore, if fruit firmness can be maintained by the same calcium treated to prevent bitter pit, it may also be useful for apple cultivation in warm regions. In the present study, the effects of calcium application in young fruit on fruit firmness, ethylene concentration, and calcium uptake were investigated.

Corresponding author: Satoru Kondo, fax : +81-824-74-1773, e-mail : s-kondo@bio.hiroshima-pu.ac.jp 


\section{MATERIALS AND METHODS}

The experiment was conducted in 2002 . The warmth index in 2002 was $109.6^{\circ} \mathrm{C}$. Six 13 -yearold 'Jonagold' apple trees (Malus sylvestris var. domestica.), grafted onto Malling 26 (M. 26) rootstocks growing in an open field at Hiroshima Prefectural University were selected for this study. The commercial harvest date of 'Jonagold' apple fruit in this area is generally from 155 to 160 DAFB. Two test groups of three trees each were created. A $2.5 \mathrm{~g} \cdot \mathrm{L}^{-1}$ calcium (Shiraishi Calcium Co., Ltd., Tokyo; $1.425 \mathrm{~g} \cdot \mathrm{L}^{-1}$ calcium sulphate dihydrate, $0.675 \mathrm{~g} \cdot \mathrm{L}^{-1}$ calcium chloride and $0.4 \mathrm{~g}$ • $\mathrm{L}^{\prime}$ others) solution was applied at 4 days intervals from 20 to 60 days after full bloom (DAFB). For the control group, a distilled water solution was sprayed as the control treatment. Each solution was applied to the whole tree using a low pressure hand sprayer.

The fruit firmness was determined by a Rheometer (NRM-2002J; Fudo Indus. Co., Tokyo; needle diameter $=1 \mathrm{~mm}$ ) after harvest. The measurement was taken at 2 places on the equator of 15 fruit ( 5 fruit per tree) at each sampling date. Nine fruit ( 3 fruit per tree) from each sample group were used for ethylene measurement. A syringe was used to take a sample from the core which was then injected into a gas chromatograph (GC-380; GL-Sciences Inc. Tokyo; column= Porapak Q, i.d. $2.2 \mathrm{~mm} \times 2.0 \mathrm{~m}$ ) to measure ethylene concentration. Five fruit randomly selected from the control group were used for anthocyanin analysis at intervals of 7 to 9 days from 149 to 179 DAFB. The anthocyanin concentration was determined by extracting skins of fixed weight with $0.32 \mathrm{~mol}$. $\mathrm{L}^{\prime}(1 \%) \mathrm{HCl}$-methanol and determining absorbance at $530 \mathrm{~nm}$ by a spectrophotometer (U-2001; Hitachi Ltd., Tokyo). The anthocyanin is expressed as cyanidin 3-galactoside equivalents.

Thirty fruit (three replicates of 10 fruit per tree) were collected at intervals of 7 to 11 days from 152 to 179 DAFB for the analysis of calcium concentration. The pulp was dried in an oven then digested by a nitric and sulfuric acid mixture. Ca concentration was then determined by atomic absorption spectrometer. The alcohol-insoluble solids (AIS) were obtained from pulp tissue as previously described (Kondo et al., 1999). Ca in AIS was extracted by $1.6 \mathrm{~mol} \cdot \mathrm{L}^{-1}(5 \%) \mathrm{HCl}$ ethanol and filtered. The residue was washed repeatedly with $13.7 \mathrm{~mol} \cdot \mathrm{L}^{-1}(80 \%)$ ethanol until no trace of chlorine could be detected. The filtrate was mixed, reduced to the aqueous phase in vacuo and $\mathrm{Ca}$ concentration was measured. Data were subjected to analysis of variance and LSD procedures were used for mean separation (SAS Inst., Inc. Cary, USA). Means were separated by standard error (SE) for anthocyanin concentrations.

\section{RESULTS AND DISCUSSION}

Soluble $\mathrm{Ca}$ concentrations in the pulp of Ca-treated fruit and untreated fruit failed to display a general tendency (Fig. 1A). It has been shown that $\mathrm{Ca}^{2+}$ acts primarily in the cross-linking of pectic polymers in the middle lamella in the cell wall (Ferguson, 1984). Apple fruit softening is accompanied by losses in uronide residues from the cell wall (Yoshioka et al., 1992). Bound Ca concentration in the cell wall of Ca- treated fruit was higher than the control (Fig. 1B). It can therefore be concluded that $\mathrm{Ca}$ treated exogenously is bound to the cell wall and may inhibit solubilization of polyuronide.

The ethylene concentration in the control fruit was higher than that in the Ca treatment (Fig. 2). The ethylene production in the control fruit decreased from 152 DAFB to 179 DAFB. It has been reported that $\mathrm{Ca}$ treatment inhibited the ACC oxidase activity that may be located in the cell wall due to the role Ca plays in the structure of cellular walls and membranes (Lara and Vendrell, 1998). In tomato fruit, ethylene synthesis stimulated cell wall degradation and advanced ripening (Brecht and Huber, 1988). Therefore, decreasing ethylene production in Ca-treated fruit implies that $\mathrm{Ca}$ treatment may delay fruit softening. Anthocyanin concentration in the control fruit 

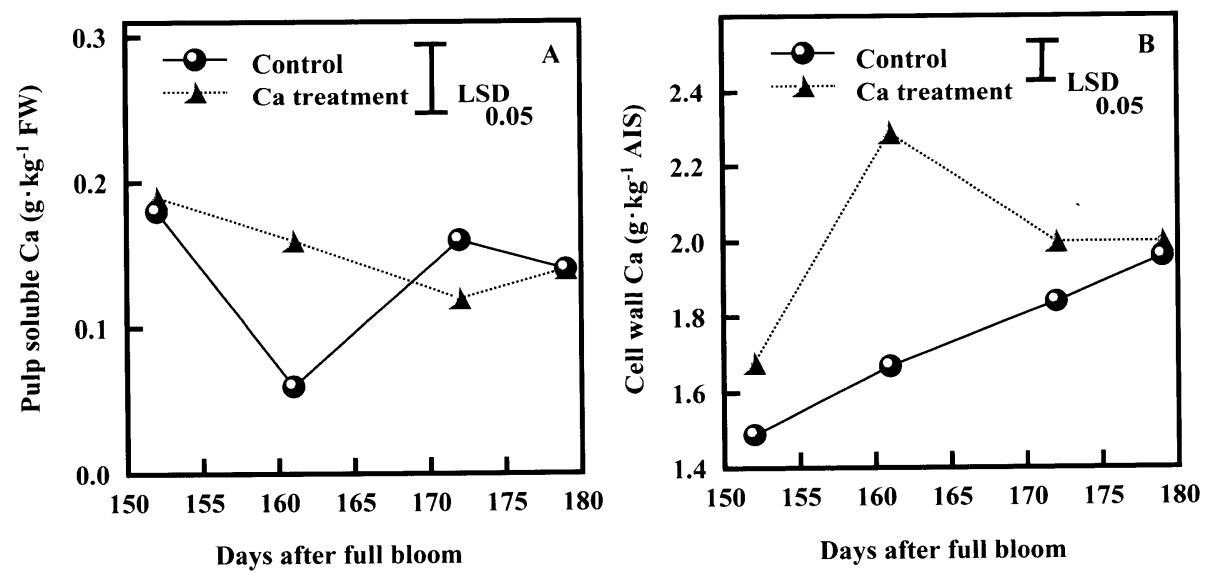

Fig. 1 Pulp soluble calcium concentration (A) and cell wall calcium concentration (B) of 'Jonagold' apple fruit treated by calcium. The $2.5 \mathrm{~g} \cdot \mathrm{L}^{-1}$ calcium solution was applied to whole tree. Each datum is the mean of 3 replicates.

increased rapidly from $0.87 \mathrm{~g} \cdot \mathrm{kg}^{-1} \mathrm{FW}$ cyanidin 3-galactoside equivalents at164 DAFB to $2.5 \mathrm{~g} \bullet$ $\mathrm{kg}^{-1} \mathrm{FW}$ at $179 \mathrm{DAFB}$ (Fig. 2). There was no significant difference in anthocyanin accumulation between the control and Ca-treated fruit (data not presented). Ethylene concentration in the control fruit reached a maximum of $8.3 \mu \mathrm{l} \cdot \mathrm{L}^{-1}$ at $152 \mathrm{DAFB}$ and then decreased rapidly until $179 \mathrm{DAFB}$. These results indicate that climacteric maximum occurred before color formation. Color is an important factor for marketable fruit. The fruit senescence prior to coloring is a major problem often observed in fruit cultivated in warm regions. Senescence is a complex process shown by the increase of ethylene, wilting, softening, abscission and so on (Abeles, 1992). Although the firmness

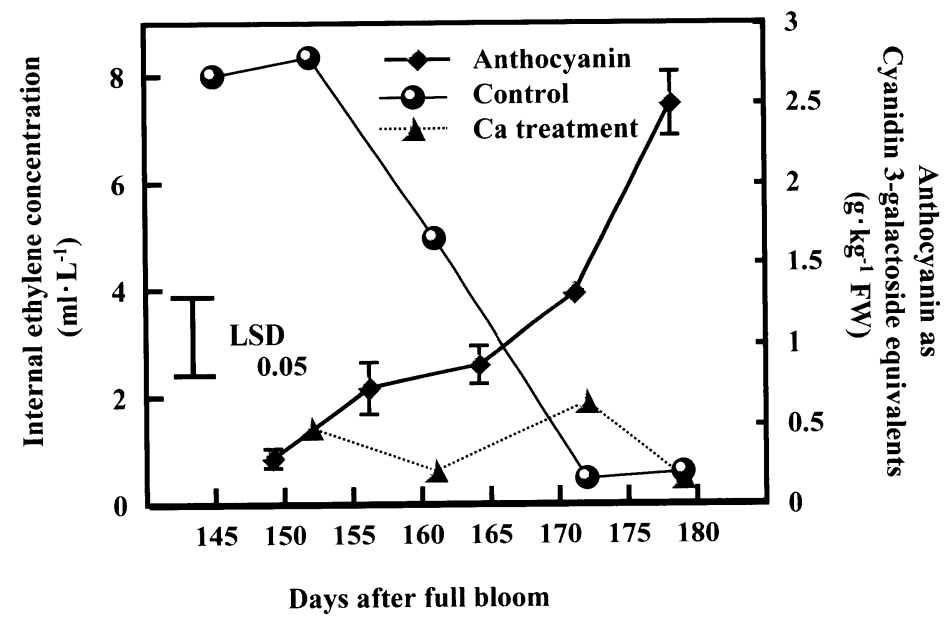

Fig. 2 Internal ethylene concentration of 'Jonagold' apple fruit treated with calcium and changes in anthocyanin concentration of control fruit. The $2.5 \mathrm{~g} \cdot \mathrm{L}^{-1}$ calcium solution was applied to whole tree. Each symbol for ethylene concentration is the mean of 9 fruit. The bar on anthocyanin concentration shows standard error. Each symbol for anthocyanin concentration is the mean of 5 fruit from the control group. 


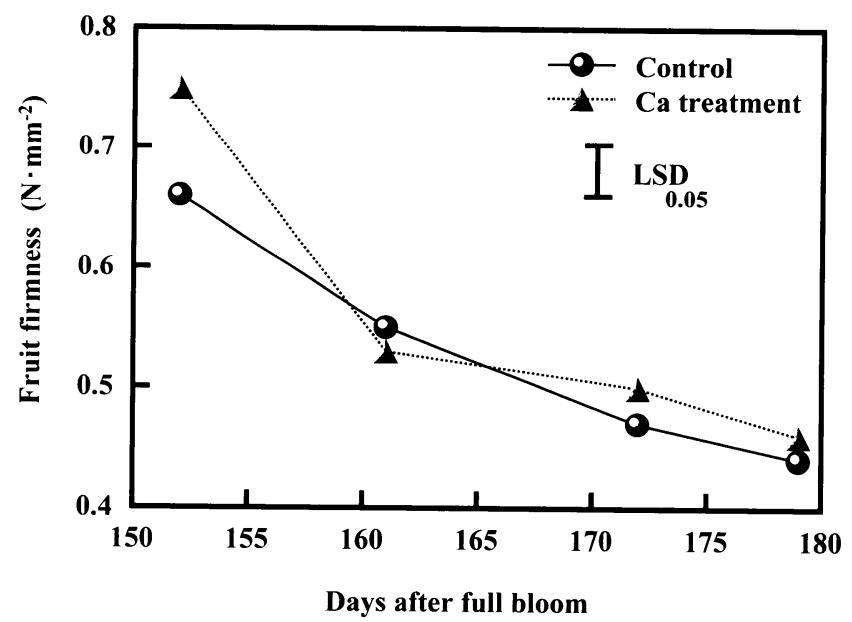

Fig. 3 Firmness of 'Jonagold' apple fruit treated by calcium. The $2.5 \mathrm{~g} \cdot \mathrm{L}^{-1}$ calcium solution was applied to whole tree. Each symbol is the mean of 15 fruit.

of Ca-treated fruit was higher than that of the control at 152 DAFB, we could not observe that $\mathrm{Ca}$ treatment maintained a greater fruit firmness than the control (Fig. 3). However, Ca application increased bound Ca concentration in the cell wall and decreased ethylene concentration in the fruit. The results of this study suggest that Ca treatment from 20 to 60 DAFB may prevent fruit senescence prior to coloring.

\section{REFERENCES}

Abeles, F. W. 1992. Roles and physiological effects of ethylene in plant physiology: Dormancy, growth, and development. In "Ethylene In Plant Biology" (ed. by Abeles, F. W., Morgan, P. W., Saltveit, M. E.), Academic Press, New York, p 120-181.

Bramlage, W. J., Drake, M., Baker, J. H. 1974. Relationships of calcium content to respiration and postharvest condition of apples. J. Am. Soc. Hortic. Sci. 99: 376-378.

Brecht, J. K., Huber, D. J. 1988. Products released from enzymically active cell wall stimulate ethylene production and ripening in preclimacteric tomato (Lycopersicon esculentum Mill.) fruit. Plant Physiol. 88: 1037-1041.

Cooper, T., Bangerth, F. 1976. The effect of Ca and Mg treatments on the physiology, chemical composition and bitter-pit development of 'Cox's orange' apples. Sci. Hortic. 5: 49-57.

Ferguson, I. B. 1984. Calcium in plant senescence and fruit ripening. Plant Cell Environ. 7: 477-489.

Kikuchi, T. 1998. Proper environment for apple cultivation. In "The System of Agricultural Technology, General Technique" (ed. by Editorial committee of the system of agricultural technology), Rural Culture Assoc., Tokyo, p 57-70.

Kondo, S., Inoue, K., Manabe, T. 1999. Cell wall metabolism of pear fruit on the tree after 2,4-DP treatment. J. Hortic. Sci. Biotech. 74: 614-617.

Lara, I., Vendrell, M. 1998. ACC oxidase activation by cold storage on 'Passe-Crassane' pears: effect of calcium treatment. J. Sci. Food Agric. 76: 421-426.

Siddiqui, S., Bangerth, F. 1993. Studies on cell wall mediated changes during storage of calcium-infiltrated apples. Acta Hortic. 326: 105-113.

Siddiqui, S., Bangerth, F. 1995. Effect of pre-harvest application of calcium on flesh firmness and cell-wall composition of apples. J. Am. Soc. Hortic. Sci. 99: 376-378.

Yoshioka, H., Aoba, K., Kashimura, Y. 1992. Molecular weight and degree of methoxylation in cell wall polyuronide during softening in pear and apple fruit. J. Am. Soc. Hortic. Sci. 117: 600-606. 